SCHOLARS: Journal of Arts \& Humanities Print ISSN: 2773-7829; e-ISSN: 2773-7837

eJournal Site: www.cdetu.edu.np/ejournal/

- Peer-Reviewed, Open Access Journal

- Indexed in NepJOL; Star-Ranked in JPPS

- Permanently Archived in Portico

\title{
From Vulnerability to Transformation: The Self in Haddon's The Curious Incident of the Dog in the Night-Time
}

\author{
Pimala Neupane \\ Department of English, Doti Multiple Campus, Doti-Silgadi, Nepal \\ Corresponding Author: Pimala Neupane, Email: pimalaneupane@gmail.com
}

\begin{abstract}
This paper examines Mark Haddon's The Curious Incident of the Dog in the Night-Time applying the theory of abjection, which portrays the self-transformation of the protagonist, Christopher Boone, from the Swindon city in the UK. He performs his extraordinary self from the subordinated condition in the novel. At fifteen, Christopher who is suffering from Asperger's Syndrome remains in a state of helplessness and vulnerable when neglected by all. However, he explores relevant ideas and effective strategies after analyzing himself and his surroundings minutely. An abject adolescent, he fails to understand others properly nor do other people clearly understand him. In the paper, I examine the protagonist's transformation into a responsible member of the family, an ethical person in the society and a savior of all the creatures. In other words, his personal self is changed into companionship from isolation, logic from disorder and life even for pet animals from a deadly situation. He not only finds out the murderer of the dog, but also he presents the reason behind actions such as the unhealthy relationship of human beings in the family and society, and their unfair treatment to other creatures. This study is descriptive-analytical and secondary data are collected from different sources in order to address the issues raised in the study. The concept of abjection as developed by Karen Coats has been adopted for analysis of the text that is the major characteristic of young adult literature.
\end{abstract}

Keywords: Abject, adolescent, investigation, neighboring dog, transformative self

\section{Introduction}

The main objective of this paper is to analyze the helpless condition of the major character Christopher Boone and his transformation as reflected in Mark Haddon's The Curious Incident of the Dog in the NightTime. To address this objective, the study has used the theory of abjection propounded by Karen Coats. The researcher argues that the protagonist, who is a vulnerable young adult and suffering from Asperger's Syndrome, transforms himself from his differently able situation to his extraordinary self by analyzing different activities, presenting his ideas with

SCHOLARS: Journal of Arts \& Humanities

\section{Article History:}

Submitted 15 November 2021

Revised 6 January 2022

Accepted 21 January 2022

Copyright Information:

Copyright 2022 (c) The Author(s). The publisher may reuse published articles with prior permission of the concerned author(s). The work is licensed under a Creative Commons Attibution 4.0 International License (CC BY 4.0).

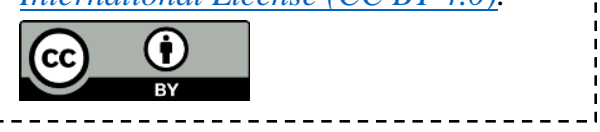

Volume 4, No. 1, February 2022 [pp. 99-108] 
logic and evidence in a scientific manner.

Christopher, in the novel, is a fifteen years old boy from the Swindon city in the UK with Asperger's Syndrome, which is a neurodevelopmental disorder, having the problems in social interaction and nonverbal communication. Due to this, he has difficulty in making friendships, involving in a two-way interaction and understanding others' feelings or body language. In other words, he is in a miserable condition in comparison with other normal human beings. Though he is living in a family, he neither gets any assistance from his family nor is he able to make his ideas that is understood to his family and people in the community. On the one hand, he is a young adult who has different capacities in comparison to other age group people, and on the other, he is a differently able person.

The study is based on the library search in which the data are qualitative in nature and are collected from different sources such as print and online sources to develop critical insights for analyzing the text, applying the theory of abjection. This theory is applicable to analyze the situation of young adults who face the transitional phase of their life. People of such groups have different changes in their behaviors and thinking. Young adults are of different natures such as aggressive, shy, creative, bold, fearful, suppressed, arrogant, depressed and so on. The protagonist Christopher, for instance, is also a young adult with the similar nature.

The abjection theory developed by Coats and interpreted by Julia Kristeva has been taken as a theoretical frame that best fits to study the text. Coats, in her writing "Abjection and Adolescent Fiction: Ways Out," defines the theory of abjection. She interrelates the term in the social and psychological context of human beings with reference to Kristeva's description that "disturbs identity, system, order...Adolescence is a time of cultivating group identity; socially abject figures cannot seem to manage either the material conditions and habits or identifications necessary to sustain a position in a social group" (138). Coats emphasizes that the abjection theory is applicable to studying young adult literature. Within this study, the young adult characters portrayed in the literature are in the process of forming their group identity. However, the abject character is unable to form his/her identity in the society or in the group. It further includes "the abjection of adolescence has traditionally been to repeat the process of repression that stabilized the oedipal identity in the first place. This has created as many problems" (Coats 152). It indicates the possibility of father-son and mother-daughter conflict. The adolescent characters are repressed in the situation when they are prevented to maintain a family relationship with their parents being attracted to the opposite gender. If they lack this, they suffer in different ways.

\section{Review of Literature}

Haddon's novel has been reviewed by several critics from different perspectives after its publication in 2003. One of important reviews is by Julia Kristeva who, in her work "The Adolescent Novel," claims that the "adolescent appears as a key personage: not only the emblem of a subjectivity in crisis, but also a means to display the psychic breakdown up" (18). Kristeva highlights the identity problem of the adolescent character that is linked with his/her identity. Disturbed psychology is unable to portray identity in a clear way. When adolescent characters do not feel free within themselves, they reflect their psychic condition in their surroundings through their behaviors or activities.

Different researchers have reviewed and researched the selected novel from different perspectives such as narrative, humor, postmodernist and stylistic. Likewise, Christiana Gregoriou reviews Haddon's novel in which the focus of her study is the narrative analysis. She notes the first-person narrative, highlighting the events with self- 
involvement. The narrative, at this point, is centered on individual evaluation and analysis of the narrators. She remarks:

The novel's first-person narrator is limited in his understanding of the world around him and hence is, narratologically, unreliable. Such first person narrators typically draw on reader sympathy and manipulate empathy toward themselves, particularly since readers are allowed access into their viewpoint and worldwide by first-person mode definition ... I more specifically use the term mind style to refer to the way in which the unusualness of language of a text relates to the unusualness of a particular character's reality, as perceived and conceptualized cognitively. (105)

Here, Christopher is narrating his experiences in the novel. He is sharing his life events with the readers through his narratives relating to different times and contexts in association with his family and society. Thus, the protagonist-narrator has depicted his personal troubles and his efforts for his transformation. All the activities narrated in the novel are centered on the major character. As the narrator himself has a kind of disability, he uses signs or symbols instead of verbal projections. At this point, he collects sympathy and empathy from the side of readers. In other words, the language used in the story is not normal that indicates the abnormal condition of the protagonist.

Laura Johansson, in her work "Humour and Handicap in Mark Haddon's The Curious Incident of the Dog in the Night-Time," demonstrates the state of humour through the disability of the protagonist and his efforts of doing different things. She asserts humour in the novel as "an autistic boy who creams when he is touched, abhors the company of other people, and fails to show and understand emotions, may not strike one as something funny. However, that assumption could not be further from the truth...a novel of paradoxes, of which the most prominent is the effortless combination of painful sadness and delightful funniness" (1). The protagonist of Haddon's novel is suffering from autism, which is at the extreme with full of its symptoms. It exists in Christopher who is unable to face social interaction or two-way communication. He screams when somebody touches him; he does not understand or convey feelings or emotions. The same character is represented as an investigator of the murder incident of the dog. These things are not accurately matched together, so Johansson calls it the humour or the paradoxical representation. The readers are unable to believe in the bold steps taken by the protagonist, so they perceive it as a matter of fun instead of truth.

Waleed Samir Ali, in the article "Mark Haddon's The Curious Incident of the Dog in the Night-Time: A Crossover Fiction Reading," analyzes the novel using the postmodern techniques. It includes blended metafiction (realism and detective fiction), different narratives, new storytelling techniques and the complexity of the character. It does not only limit the children readers, but also it demands the adult readers. In other words, it requires multiple readerships. Ali overviews Haddon's novel in this way:

By establishing the unique nature of his protagonist, Haddon has created a great sense of defamiliarization on the part of the readers, the majority of whom cannot identify with Christopher for his disability. In addition, Christopher's character is unlikely to make him the hero of a story in conventional fiction. Haddon presents his novel as a coming-of-age story of a 15-year-old boy with autism who views the world from his own perspective. However, Haddon employs several devices to involve the wide range of his readership, both young and adult. (605)

Ali figures out the dual-aged character that crosses from children to adults and adults to children in Haddon's novel. The protagonist has different capacities. It requires multiple readerships including young and adult. In other words, it does not claim the single idea, 
character, theme, story and readership. Hence, it carries multiple ideas and projections. Along with this, the novel is analyzed from the stylistic perspective in which the researcher illuminates the language barriers to the protagonist while communicating with others. Christopher as a member of a society uses different linguistic or stylistic signs, but his efforts in sharing and understanding messages with other people have not been successful. The language and style of his communication are not similar to other people. Instead of verbal depiction for communication, "visual imagery is an important aspect of Christopher's thinking process ... avoidance of complexity at phrase level and repetition of lexis and sentence structures indicate and reflect that he is unable to construct the minds and mental states of other people and that he has a strong need for order and clarity" (Luckin 25-26). Christopher uses visual images such as signs, symbols, or pictures for communicating his ideas. He has difficulty in using words or substructures of the sentences because of his mental status that is in the form of high functioning autism, which is known as Asperger Syndrome. So, he has problems in two-way interaction with other people. Neither he understands the ideas of other people nor does his own way of communication become understandable to others. Therefore, the communication requires in proper structure or form what the protagonist is lacking.

The researcher finds out that Christopher is in a pitiful condition and faces negligence from all people including his family members. Though he is conveying the logical ideas about his father's extramarital affairs with his neighbor, Mrs. Eileen Shears, and the murder of a dog, Wellington, nobody listens to Christopher and recognizes his strengths. This problem in this text is not addressed anywhere by anyone though some researchers have studied other issues. At this point, the researcher has raised this issue of the novel while preparing this paper.

\section{Christopher's Struggle for His Self}

In the novel, Christopher comes across a series of events while investigating the murder of a neighboring dog such as misunderstanding with the policeman, alienation or fragmentation in family, difficulty in coping with other people who question his work. Mostly, people do not find any meaning in his effort of doing everything that he claims as a mathematical way. While doing nothing other than visiting and hugging the dog at the time, Mrs. Shears shouts and screams at the boy and calls the police. Christopher's father restricts him for not doing anything with their neighbor. But, as a result of his activities, he becomes curious to find out the cause of the murder of the dog and the reason for killing it; he becomes able to reveal the murderer of the dog and the secrecy of his parents' relationship and his existence.

Christopher involves in the investigation without any concern of other people including his father. He attempts to express his feelings through pictures or signals to express sadness for the death of the dog and happiness while reading about the Apollo space missions according to his interests in mathematics. Along with the involvement in investigating Wellington's murder, people take his interest in mathematics and science lightly. In contrast, he is the only one to prove himself not only as the discoverer of the actual murderer of the dog, but also an efficient manager of the family relationship by identifying the extra-marital relationship of the father and playing a proper role to unite his parents.

Christopher, who is lonely and unable to communicate with the outside world, has desires to be with a dead dog, exploring human reality and their communities. There are unusual incidents and human misconduct in the surroundings where he is living. Though people undermine him, he scrutinizes each and every situation very critically and creatively. He investigates mysterious conditions, illusions and adultery of people 
including his loneliness. He presents logical findings with solutions. The protagonist technically invests his efforts to change the illusion into clarity, separation into the union, disorder into order and challenges into opportunities. Apart from this, he explores the world through his writing by including only the prime numbers and excluding other numbers. By doing this, he tries to prove himself successful in mathematics, creating something unique over commonalities.

Christopher claims himself to be intelligent over other people who are talking about him as homesick. Instead of that, he is willing to be surrounded by computers and outer space. In response to people who think of him as an uncommon adolescent boy as Sabina Dosani calls the condition "brain disorder" (33). Unlike the comments from other people, he challenges everyone with his words:

I would be able to look out of a little window in the spacecraft and know that there was no one else near me for thousands and thousands of miles which is what I sometimes pretend at night in the summer when I go and lie on the lawn and look up at the sky and I put my hands round the sides of my face so that I can't see the fence and the chimney and the washing line and I can pretend I'm in space. (65-66)

It shows Christopher's self-existence where he sees himself in relation to the universe. He claims that he wants to be an astronaut that his respect and admiration for the universe are clearly deep-seated. This is his escape from the world that is known as full of man-made commodities. He articulates himself as in the higher determinative world in response to common people thinking about him. Without accepting the way everyone else sees the world, this is his connection with something he utterly admires and feels connected to a logical-mathematical world that functions because of the detailed precision of his intellect. He prioritizes his subjectivity as Janet Alsup foresees, "personal subjectivity as part of a larger system of social relationships" (13). Christopher as a member of the family and society, his activities are directly concerned with the place where he lives. Familial and social wellbeing is also associated with personal subjectivity. Only after subjective value, he transforms his objective identity. When he remains in measurable situations, no one is interested to listen to him. As a reflection of his strengths, people assume that he is changing himself into a discoverer, using his logic.

Haddon rewards the protagonist, with a real sense of authorship in the text, who does not like metaphorical language. The language used in the novel is very particular to the character Christopher and the character has a very specific relationship with that language. It is because the novelist does not like exaggerated facts or modified truth. $\mathrm{He}$ does not prefer any lie to relate in his life that portrays "the experiences of the subject" (Kristeva 14). Christopher is sharing his interests or experiences in the area to which he is dedicated. To emphasize reality instead of imagined ideas or artificial information, the novelist projects his voice through his character based on rationality and fact:

Mostly I read books about science and maths. I do not like proper novels. ... But I do like mystery novels. So I am writing a murder mystery novel.

In a murder mystery novel someone has to work out who the murderer is and then catch them. It is a puzzle. If it is a good puzzle you can sometimes work out the answer before the end of the book. (5)

Haddon has shown Christopher performing actions, hiding his own identity in the novel to reveal the reality. Christopher is speaking the voice of the novelist in the book.

Haddon himself becomes a character and the character claims himself as a writer. In a similar way, reading maths and science books juxtaposes a reason or logic over the traditional ideas. Writing a murder mystery novel relates the subjective identity of the 
novelist, presenting it through his character. The character is imitating the novelist's identity. Kristeva, in this context, states, "Abjection is a resurrection that has gone through death (of the ego). It is an alchemy that transforms death drive into a start of life, of new significance" (15). Kristeva shows the abjection in imitation of identity where a new one emerges in absence of another. Christopher also represents the story of an adolescent boy by carrying the voice of the novelist in his absence. He has adopted the role of Christopher to tell the story and to convey the fact. In this context, the novelist is presenting not only his subjective identity, but also the identity of the character through his writing. The character in the text is iterating the voice of the author. As_Jane Kroger argues, "Kegan refers to a subject-objective (self -other) relationship in balance as an evolutionary truce. More accurately, '[e]volutionary truces establish a balance between subject and object"" (147). Kroger emphasizes that representing the self and other relationships in a balanced way is an evolutionary task that represents multiple voices in an organized way. Partially, it carries the essence of subject and object, but it is not completely bounded at one part.

Christopher reflects that he wants to interlink his world with the world of animals. He is inquisitive not only about human activities, but also he is about animal behaviors. Along with this, he finds the pathetic situation of animals within himself. He asserts the life of humans and animals at the same time in order to maintain mutual harmony. He expresses, “'I didn't know I was going to get into trouble. I like Wellington and I went to say hello to him, but I didn't know that someone had killed him.' ... 'I wonder if the police will find out who killed him and punish the person'" (26). It requires an order or a reason for every action. The protagonist concentrates on investigating the fact about the murder of the dog. He keeps on continuing this investigation process unlike his father's interest, who offers only to do his own tasks but denies paying attention to Wellington and collects information from different sources. Christopher's intention to maintain order or justice in the society at the time becomes "fruitless attempts to identify with something on the outside, finds the impossible within... that it is none other than abject" (Kristeva 5). Christopher expects to find out logical evidence over the incident of the dog. He is unable to complete the task, so he wants the policeman to find out the murderer of the dog and punish the person. Christopher, as an abjected self, is limited within his expectation instead of fulfilling his desire of finding out and punishing the murderer.

The protagonist-narrator makes his efforts to be courageous for exploring reality with his mathematical mind. Bravery or feeling of superiority is also the characteristic of adolescence. As an adolescent, he takes his bold steps to involve in the "series of discoveries" (Siegelman 50) to find out the fact or evidence of the murder incident of the dog. He compares himself with the great detective of London when he claims, "Sherlock Holmes had, in a very remarkable degree. . . I get really interested in something, like practicing maths, or reading a book about the Apollo missions" (92). Christopher wants to explore the world through mathematical practices for finding out reasons, or actual truths from analysis and experimentation. He disconnects himself from other normal people of this existing world in order to think clearly without distraction. He does not think of himself as inferior as people of his family and society undermine him. In opposition to this, he tries to privilege himself as in the position of the mathematician by "[f]ollowing the example of Sherlock Holmes he decides to do some detecting to solve the mystery of who killed his neighbor's dog" (Thistlethwaite 815). The protagonist moves further to fulfill his inner concerns of the murder incident about Wellington despite his own difficulties. 
There is no one to listen to Christopher, but he converts his dreams into action as it relates to the "abjection of self to show that all abjection is in fact recognition of the want" (Kristeva 5). He himself involves in the investigations, following the scientific ways to find out the reasons behind the murder incident. Involving continuously to study the murder of the dog, he comes to know the truth that his father is a murderer who also lives in an illegal relationship with the neighbouring woman. After this, his activities hurdle his relationship with his father to bring out secrecy related to the event into public. This inclines Christopher to make the decision not to stay with his father. As Christopher says, "I couldn't live in the house with father anymore because it was dangerous" (160). He thinks himself in danger from his father who killed the dog also is possible to kill the son. The perception of the deficiency of Christopher does not limit within himself, but it spreads into other spheres with his efforts of finding scientific reasons behind the murder incident. He becomes successful in his effort; however, the outcomes of his investigation create problems for others who involve in fraudulent activities including his father. Further, it creates an uncomfortable situation in the family, so he makes another decision for leaving his home and father. He prefers truth, logic, or reason over the family relationship.

\section{Christopher's Self-Transformation}

Christopher is struggling to exist from an ethical, moral and fundamental ground in the society where he is living. The social norms and practices hinder his interests and dedication for which people do not understand him. The situation occurs because of his parents' lack of understanding about the adolescent child. Not only the family but also the society excludes him as other among the members of the same group. It is more problematic context to "psychologically abject character whose abjection defines his or her way of being in the world" (Coats 139). Christopher is isolated from the people of his community. His world of understanding is different from the people in his society. As an abject character, he defines his own way of thinking and behavior that is not comprehensive to other people who have their different world. Evangelia Lambidoni reviews, "The garden fork stuck in the dog's body and the blood does not stop Christopher from hugging the dead animal. The police who arrive at the scene also fail to recognize Christopher's good intentions" (95). Christopher fails to understand the policeman's point of view. When the protagonist involves in hugging the dead dog, the boy becomes the primary suspect, so he gets frustrated and overreacts with the questions of the policeman. It shows the deficits of an adolescent boy in coping with the situations, beliefs, intentions and desires of other people. His aspiration is to find out the causes and evidence of the murder of the dog. However, he is blamed as the murderer only for visiting the dog.

In a similar manner, Christopher creates his identity as a capable person out of his abnormal condition and obstacles from other people. He is living without a proper care of anyone in the family. His position as a member of the society is not secure as other normal people in the society. At this point, the protagonist is in a similar condition as other "abject characters ... act as foils and props for establishing the clean and proper identity of the normal protagonists" (Coats 151). As a neglected young adult who is also lacking a regular care from his parents, he finds out another fact about his parents and the relationship. His father has lied to him about the death of his mother although she is still alive. On the contrary, he reads the letter from his mother. He utters:

Then I stopped reading the letter because I felt sick.

Mother had not had a heart attack. Mother had not died. Mother had been alive all the time. And father had lied about this. 
From Vulnerability to Transformation: The Self in Haddon 106

I tried really hard to think if there was any other explanation but I couldn't think of one. And then I couldn't think of anything at all because my brain wasn't working properly. (141)

It becomes painful for Christopher because of an ill-treatment of the people towards him. He becomes a victim even from his father who lies about the death of his mother.

However, he receives the letter from his alive mother. While reading the letter of his mother, he feels himself sick and acquires the channelized past events narrated in the letters, which click him about reality. He identifies the false statement of his father about the death of the mother or her sickness with the heart attack. So, he restates his dilemma between life and death, reality and illusion, past and present, and self and others along with his capability of finding facts. Coats has added something for such a situation that the "work through abjection ... what is unthinkable can return, that death can infect life. ... it is our children who are teaching us that we must bear the weight of this knowledge, rather than continue to build our lives on its exclusion" (159). Coats affirms that even in despair and death, certain knowledge related to life exists in the real ground. With the help of self-knowledge or perceptions and the responses, even the work of an abject one can be useful for the society. He finds out the reality over illusion about the murder mystery compelling his father to tell the truth as he confesses, "And he said, 'I Killed Wellington, Christopher"' (245). After knowing the reality of the murder, Christopher determines to live separately from his father and moves to London to seek his mother who is alive. Christopher as a differently able person discovers evidence over different incidents. He generates knowledge to come out from the pathetic situation that makes him a hero of his actions.

The adolescent protagonist is determinative in his goal, which is just the opposite of people's assumptions about him. He has not known anything from others about mysterious death incident of a dog, the truth about his mother and writing a real nature of adolescence book instead of listening to false assumption of undermining young adult. He gratifies himself through his efforts in doing different things as he states, "I know I can do this because I went to London on my own and because I solved the mystery of who killed Wellington, and I found my mother and I was brave and I wrote a book and that means I can do anything" (268). It proves that Christopher becomes successful to change every situation into reality concerning with his self, which helps him to reveal the murder mystery, find his alive mother and explore the world through his fifteen years of his life.

Finally, Christopher transforms himself from sadness to happiness, helpless or vulnerable condition to success. He experiences different unpleasant situations and feels uncomfortable living in London after knowing his father as a murderer. He insists that he wants his mother to return to Swindon as he utters, "I wanted to go home and go to my room and feed Toby and practice some maths" (75). He becomes happy and satisfied with himself after coming back home with his mother as he says, "I got the results of my Maths A level and I got an A grade which is the best result and it made me feel like this...And I called the dog Sandy" (266-267). He approves himself that he is able to improve the level of his happiness that he has achieved from puzzles, success from failure and order from disorder. He is able to identify his capability in Maths and feels joyful over his success. He realizes that all this happens with his continuous efforts to achieve his goal as a "mathematical genius" (Suellen and Linda 105). He becomes successful to transform his individual self by making seemingly impossible situations possible to make his 'self' pleasant, successful and satisfied. He proves his existence as a mathematician, mediator and investigator. In other words, he creates a balance of his life 
forming an extraordinary self, playing a key role to unite parents and discovering facts about the murder incident of the dog in order to establish justice in the society.

\section{Conclusion}

Christopher as a fifteen-year-old boy with Asperger's Syndrome portrays his individual self that is neglected by everyone including family members and other people in his community. He is unable to maintain proper communication, build a relationship and understand others in a proper way. He is treated as immature, deficient, weak and unsuccessful from the beginning. He becomes helpless with his own deficiency and people's ill-treatment towards him. In other words, his voice is not heard and his activities are not addressed anywhere. From this vulnerable situation, he struggles hard to transform himself, his family and society.

The protagonist as a young adult makes his efforts in maintaining order or system despite his own deficiency. He analyzes his surroundings and finds disorder in the family, crime in the neighborhood and injustice in the community. Along with his lonely condition in the family, he discovers the issue of his parents' separation, his father's illegal relationship with a neighboring woman, Mrs. Shears, and the policeman's inability to find out the murderer of the dog. He has studied every event minutely, analyzed those events through symbols or signs and found out the truth with his experiments.

Finally, Christopher's goal is to be successful in mathematics and his efforts for fighting unfair treatment in his surroundings with logic and evidence. They ultimately become meaningful. He proves himself as an intelligent and responsible person who has created unity from isolation in the family, discovers the world identifying appropriateness and explores the world of young adults projecting himself as an author who converts the personal issues into public. As an adolescent, he involves in the investigation of the murder incident of the dog in his neighborhood, continuously follows the way to find his mother who has already left home and keeps on his intellectual journey with his critical evaluation and experiment. As a result, he resembles his situation into an important young adult from a helpless situation by following moral, ethical, social and intellectual ground. He identifies himself as an author of a murder mystery novel, performs a major role to unite his family and discovers the murderer, establishing order or system in the community. He becomes successful to transform his identity as an extraordinary self, a valuable member of the family and a responsible person in his society.

\section{Works Cited}

Alfred, Suellen, and Linda Null. "A Mind with a View." The English Journal, vol. 95, no. 4, March 2006, pp. 105-107. JSTOR, www.jstor.org/stable/30047100.

Ali, Waleed Samir. "Mark Haddon's The Curious Incident of the Dog in the Night-Time: A Crossover Fiction Reading." CDELT Occasional Papers in the Development of English Education, vol. 66, no. 1, 2019. pp. 597-620.

Alsup, Janet, editor. "Identity, Actualization, or Education: Why Read YAL?" Young Adult Literature and Adolescent Identity across Cultures and Classrooms: Contexts for the Literary Lives of Teens. Routledge, 2010, p. 13.

Coats, Karen. "Abjection and Adolescent Fiction." Looking Glasses and Neverlands: Lacan, Desire, and Subjectivity in Children's Literature. University of Iowa Press, 2004, p. 137-160. ProQuest Ebook Central, www.ebookcentral.proquest.com/lib/tribhuvannp/detail.action?docID=843141.. Accessed on 29 December 2021. 
Dosani, Sabina. "Back on the Autistic Spectrum." British Medical Journal, vol. 345, no. 7870, 18 August 2012, p. 33. JSTOR, www.jstor.org/stable/23278311..

Gregoriou, Christiana. "The Poetics of Deviance in The Curious Incident of the Dog in the Night-Time." The Millennial Detective: Essays on Trends in Crime Fiction, Film and Television, 1990-2010. Edited by Malcah Effron, McFarland \& Company, Inc., 2011, p. 105.

Haddon, Mark. The Curious Incident of the Dog in the Night-Time. Vintage Books, 2003.

Johansson, Laura. Humour and Handicap in Mark Haddon's The Curious Incident of the Dog in the Night-Time. Master's Thesis, University of Tampere, 2008.

Kristeva, Julia. "Approaching Abjection." Powers of Horror: An Essay on Abjection. Translated by Leon S. Roudiez, Columbia UP, 1982, pp.5-15.

---. "The Adolescent Novel." Abjection, Melancholia, and Love: The Work of Julia Kristeva. Edited by John Fletcher and Andrew Benjamin. Vol. 4, Routledge, 2012, pp. 8-23.

Kroger, Jane. "Identity as Meaning Making: Kegan's Constructive-Developmental Approach." Identity in Adolescence. Routledge, 2004, p. 147.

Lambidoni, Evangelia. "Life Viewed through the Eyes of a Child with Autism." The Journal of Education, vol. 188, no. 1, 2007, pp. 93-109. JSTOR, www.jstor.org/stable/42744124.

Luckin, Nadja. Language and World View: Mind Style in Mark Haddon's The Curious Incident of the Dog in the Night-Time. MA Thesis, University of Oslo, May 2013. www.duo.uio.no/..

Siegelman, Ellen Y. "An Anti-Hero's Journey." The San Francisco Jung Institute Library Journal, vol. 24, no. 2, May 2005, pp. 47-57. JSTOR, www.jstor.org/stable/10.1525/jung.1.2005.24.2.47.

Thistlethwaite, Jill. "Review of The Curious Incident of the Dog in the Night-Time by Mark Haddon." British Medical Journal, vol. 327, no. 7418, 4 Oct. 2003, p. 815. JSTOR, www.jstor.org/stable/25457420.

\section{To cite this article [MLA style]:}

Neupane, Pimala. "From Vulnerability to Transformation: The Self in Haddon's The Curious Incident of the Dog in the Night-Time." SCHOLARS: Journal of Arts \& Humanities, vol. 4, no. 1, February 2022, pp. 99-108. NepJOL, doi:10.3126/sjah.v4i1.43059. 